\title{
PENGARUH KEPRIBADIAN DAN SITUASI TERHADAP PEMILIHAN MAKANAN PADA MAHASISWA TINGKAT PERTAMA
}

\author{
Mutiara Purnamawati ${ }^{*}$, Lilik Noor Yuliati \\ Departemen IImu Keluarga dan Konsumen, Fakultas Ekologi Manusia, Institut Pertanian Bogor \\ 16680, Indonesia \\ *)Email: mpmutzia@gmail.com
}

\begin{abstract}
Abstrak
Penelitian ini bertujuan untuk: (1) mengidentifikasi kebiasaan konsumsi sayur pada mahasiswa tingkat pertama sebelum dan sesudah masuk ke asrama; (2) menganalisis kepribadian, situasi, dan pemilihan makanan berdasarkan jenis kelamin; dan (3) menganalisis faktor-faktor yang memengaruhi pemilihan makan sayur pada mahasiswa tingkat pertama. Penelitian ini melibatkan 288 mahasiswa tingkat pertama di IPB (121 mahasiswa laki-laki dan 167 mahasiswa perempuan) yang berasal dari 3 kelas (P09, Q03, R02) dan diperoleh melalui cluster random sampling. Data dikumpulkan melalui metode self-administered dengan menggunakan kuesioner. Varibel yang diukur terdiri dari karakteristik contoh (uang saku, umur, dan jenis kelamin), kebiasaan konsumsi sayur, kepribadian (neuroticism, extraversion, openness to experience, agreeableness, dan conscientiousness), situasi, dan pemilihan makanan (sayur). Hasil penelitian menemukan bahwa kepribadian (extraversion, openness to experience, dan agreeableness) dan situasi (ketika makan di rumah) berpengaruh positif terhadap pemilihan makan sayur pada mahasiswa tingkat pertama. Artinya bahwa contoh yang memiliki sifat senang bersosialisasi (extraversion), memiliki sifat kreatif dan imajinatif (openness to experience), memiliki sifat ramah dan peka terhadap lingkungan (agreeableness) akan semakin memilih makan sayur. Selain itu, situasi ketika makan di rumah juga memicu contoh untuk lebih sering mengonsumsi sayur.
\end{abstract}

Kata kunci: kepribadian, pemilihan makanan, situasi makan

\section{The Effect of Personality and Situation on Food Choices among First Grade Student College}

\begin{abstract}
This study aims to: (1) identify the habits of vegetable consumption among the first grade students before and after entering the dormitory; (2) analyze the personality, situation, and the food choices based on gender; and (3) analyze the factors that influence the food choices among the first grade students. This study included 288 students in the first grade (121 male students and 167 female students) that selected by cluster random sampling. Data were collected by self-administered methods. Variables measured consist of characteristic samples (allowance, age, and gender), vegetable consumption habits, personality (neuroticism, extraversion, openness to experience, agreeableness, and conscientiousness), the situation (places to eat), and the food choices (vegetables). This study found that personality (extraversion, openness to experience, and agreeableness) and situations (eating at home) had a positive influence on the food choices (vegetables). This means that the sample which had good socialize (extraversion), creative and imaginative (openness to experience), friendly and environmentally sensitive (agreeableness) would increase the choose to eat vegetables. Moreover, sample more ate vegetables when they were at home.
\end{abstract}

Keywords: personality, food choices, eating situation

\section{PENDAHULUAN}

Makanan merupakan kebutuhan pokok yang tidak pernah lepas dari rutinitas manusia sehari-hari. Teori Maslow menjelaskan bahwa kebutuhan pertama yang dibutuhkan oleh manusia adalah kebutuhan fisiologis sehingga pemenuhan kebutuhan untuk fisik manusia merupakan hal yang paling utama agar seseorang dapat mempertahankan hidupnya (Sumarwan, 2011). Konsumsi makanan yang bergizi merupakan suatu keharusan bagi seorang individu agar kondisi kesehatan tetap terjaga, tidak mudah terserang penyakit, dan memenuhi gizi yang seimbang. Pada umumnya, orang dewasa cenderung mengadopsi kebiasaan konsumsi makanan sehat jika kebiasaan tersebut sudah dilakukan 
sejak usia dini (Chan et al., 2009). Saat ini, kebiasaan konsumsi makanan sehat telah berubah akibat perkembangan ekonomi yang begitu pesat. Hal ini ditandai dengan akses yang semakin mudah terhadap makanan yang tidak sehat dan juga harga yang lebih murah dibandingkan dengan makanan sehat (Henningsen, 2011).

Salah satu jenis makanan sehat adalah sayuran. Berdasarkan Riset Kesehatan Dasar (2013), penduduk dikategorikan 'cukup' mengonsumsi sayur dan/buah apabila makan sayur dan/buah minimal lima porsi per hari selama tujuh hari dalam seminggu dan dikategorikan 'kurang' apabila konsumsi sayur dan/buah kurang dari ketentuan tersebut. World Health Organization (WHO) juga merekomendasikan konsumsi sayur dan buah sebanyak 400 gram per hari. Hasil penelitian Gustiara (2012) menemukan bahwa frekuensi dan jumlah konsumsi sayur murid SMA di lokasi penelitiannya tergolong rendah, yakni hanya kurang dari 2 kali per hari dan jumlah konsumsi sayur masih di bawah anjuran konsumsi sayur, yakni minimal lima porsi per hari.

Hasil penelitian Saufika et al. (2012) menemukan bahwa mahasiswa perempuan berpeluang 3,006 kali lebih tinggi untuk memiliki kebiasaan makan camilan dibandingkan dengan mahasiswa laki-laki. Jika dilihat dari sisi sosiodemografis, wanita berusia 50-60 tahun memiliki kebiasaan mengonsumsi makanan sehat lebih sering dibandingkan dengan wanita yang usianya lebih muda, sedangkan untuk laki-laki kecenderungan untuk mengonsumsi makanan sehat adalah pada usia 60 tahun (Laaksonen et al., 2007). Hal ini menunjukkan bahwa kalangan anak muda masih kurang dalam hal asupan makanan sehat, khususnya sayuran.

Eertmans (2006) menjelaskan bahwa pemilihan makanan ditentukan oleh tiga faktor, yaitu makanan, individu, dan lingkungan atau situasinya. Selanjutnya, secara umum terdapat 4 peringkat teratas dalam motivasi yang paling penting dalam pemilihan makanan, yaitu kenyamanan, kesehatan, harga, dan faktor kesukaan. Ketika persepsi seseorang mengenai makanan stabil maka tindakan seseorang terhadap persepsi ini bervariasi tergantung dari ketersediaan makanan pada suatu lokasi atau tempat dan pengaruh sosial dari orang lain (Brown et al., 2015).

Faktor kepribadian atau kodisi psikologis merupakan faktor yang berasal dari dalam diri individu dan dapat memengaruhi pemilihan makanan, contohnya menurut Lunn et al. (2014), seseorang yang berkeperibadian openness to experience cenderung lebih memilih mengonsumsi sayur dan buah. Kepribadian memiliki pengaruh dalam pemilihan makanan seseorang. Salah satu penelitian yang mengkaji pengaruh kepibadian terhadap pemilihan makanan menunjukkan bahwa seorang individu yang memiliki sifat conscientiousness akan lebih memperhatikan pemilihan makanan yang direkomendasikan oleh panduan diet (dietary guidelines) yang berarti makanan yang dipilih adalah makananmakanan yang bergizi dan baik untuk kesehatan (Keller \& Siegrist, 2015).

Penelitian mengenai hubungan kepribadian dan diet menjelaskan bahwa terdapat hubungan antara faktor kepribadian, neuroticism, dan kesuksesan penurunan berat badan dengan treatment penurunan berat badan tertentu. Sementara itu, dengan mengkaji pengaruh kepribadian terhadap pemilihan makanan dapat diketahui tipe-tipe kepribadian yang memiliki kecenderungan untuk lebih mempertimbangkan kriteria-kriteria pemilihan makanan tertentu dan dapat diketahui pula tipe-tipe kepribadian yang memengaruhi pemilihan makanan mahasiswa (Munro et al., 2011).

Selain kepribadian, situasi merupakan faktor yang berasal dari luar diri individu yang juga dapat memengaruhi pemilihan makanan. Sebagai contoh ketika seseorang berada pada situasi makan di restoran dan dihadapkan pada menu yang banyak menyajikan makanan sehat maka orang tersebut akan semakin cenderung untuk memesan makanan sehat tersebut (Choi \& Zhao, 2012). Penelitian yang dilakukan oleh Vandevijvere et al. (2009) menemukan bahwa orang yang sering berada pada situasi makan di luar rumah (Substantially Out of Home/SOH eaters) cenderung lebih banyak memilih mengonsumsi makanan yang rendah nutrisi, padat energi, seperti snacks, minuman berkarbonasi, dan alkohol jika dibandingkan dengan orang yang tidak sering makan di luar rumah.

Beberapa penelitian sebelumnya mengenai topik pemilihan makanan, seperti penelitian Wang et al. (2015) tentang pemilihan makanan tradisional dan makanan western, serta penelitian dari Ensaff et al. (2012) tentang pemilihan makanan anak di sekolah. Penelitian mengenai topik pemilihan makanan ini dirasa menarik untuk dikaji karena remaja Indonesia masih mengalami masalah mengenai 
konsumsi sayur, seperti yang dijelaskan dalam penelitian dari Achmad et al. (2014) bahwa rata-rata konsumsi sayur anak remaja di dua SMA di Makassar masih di bawah anjuran gizi seimbang, yakni 250 gram/hari.

Oleh karena itu, penelitian yang mengkaji pemilihan makanan pada mahasiswa tingkat pertama yang tinggal di asrama; yang tentu saja berbeda situasinya antara sebelum dan sesudah masuk asrama perlu dilakukan. Berdasarkan hal tersebut maka penelitian ini memiliki tujuan, yaitu 1) mengetahui kebiasaan konsumsi sayur mahasiswa tingkat pertama sebelum dan sesudah masuk asrama, 2) menganalisis kepribadian, situasi, dan pemilihan makanan berdasarkan jenis kelamin, dan 3) menganalisis faktor-faktor yang memengaruhi pemilihan makan sayur pada mahasiswa tingkat pertama.

\section{METODE}

Penelitian ini menggunakan disain cross sectional study dan dilaksanakan di Kampus Institut Pertanian Bogor (IPB), Kecamatan Dramaga, Kabupaten Bogor, Jawa Barat. Pemilihan lokasi penelitian dilakukan secara purposive dengan pertimbangan bahwa IPB menerapkan mahasiswa tingkat pertama untuk wajib tinggal di asrama. Transisi dari rumah menuju kehidupan di asrama tentu saja merupakan perubahan lingkungan baru yang dihadapi mahasiswa tingkat pertama IPB. Penelitian ini dilaksanakan pada bulan Februari sampai Mei 2016 yang meliputi penyusunan proposal, pengujian kuesioner, pengambilan data, pengolahan data, dan penulisan laporan.

Populasi dalam penelitian ini adalah mahasiswa semester 2 Strata-1 (S1) yang berkuliah pada Tahun Akademik 2015/2016. Mahasiswa tingkat pertama dipilih dengan pertimbangan mahasiswa baru yang datang dari berbagai daerah dan belum banyak terpengaruh oleh perilaku makan di lingkungan yang baru. Oleh karenanya, penelitian ini ingin membandingkan bagaimana pola konsumsi sayur sebelum dan sesudah masuk asrama IPB yang wajib untuk mahasiswa tingkat pertama, serta bagaimana pengaruh kepribadian dan situasi terhadap pemilihan makanan dalam hal ini sayur. Mahasiswa tingkat pertama IPB memiliki jumlah sebanyak 3.595 mahasiswa. Teknik penarikan mahasiswa tingkat pertama menggunakan teknik probability sampling, yakni cluster random sampling. Cara pengambilan mahasiswa tingkat pertama mulai dari sejumlah 33 kelas di tingkat pertama IPB yang terdiri dari kelas $\mathrm{P}, \mathrm{Q}, \mathrm{R}, \mathrm{S}, \mathrm{T}, \mathrm{U}$ yang dipilih menjadi 3 kelas secara cluster random sampling. Selanjutnya diperoleh sebanyak 288 responden dan kelas yang dijadikan sebagai sampel yakni seluruh mahasiswa dari kelas P09, Q03, dan R02.

Data yang digunakan adalah data primer. Data primer meliputi data yang langsung didapatkan dari responden, antara lain karakteristik mahasiswa tingkat pertama (usia, jenis kelamin, uang saku), kepribadian, situasi, pemilihan makanan, serta jumlah, frekuensi, dan jenis sayuran yang dikonsumsi mahasiswa sebelum dan sesudah masuk asrama IPB. Data sekunder hanya digunakan untuk menentukan jumlah mahasiswa tingkat pertama. Data sekunder diperoleh dari Direktorat PPKU (Program Pendidikan Kompetensi Umum) mengenai data kelas serta jumlah mahasiswa PPKU. Sementara itu, data primer diperoleh dengan cara mengunjungi langsung responden dari kelas P09, Q03, dan R02. Kuesioner dibagikan secara merata kepada seluruh mahasiswa dari ketiga kelas tersebut.

Karakteristik mahasiswa tingkat pertama meliputi uang saku, umur mahasiswa, dan jenis kelamin. Pengkategorian uang saku mahasiswa dibagi menjadi tiga, yakni: (1) SRp600.000, (2) Rp600.000-Rp1.000.000, dan (3) >Rp1.000.000. Ketiga kategori uang saku ini merupakan uang saku per bulan mahasiswa. Umur mahasiswa diolah berdasarkan tahun, sedangkan jenis kelamin dibagi menjadi laki-laki dan perempuan.

Kepribadian adalah stabilitas beberapa pola perilaku, tindakan atau respon pada situasi yang seseorang hadapi, termasuk pola pikiran dan perasaan (John et al., 2008). Pengukuran kepribadian mahasiswa tingkat pertama menggunakan kuesioner NEO PI-3 yang diadaptasi dari McCrae et al. (2005) dengan jumlah 37 pernyataan dan menggunakan skala Likert 5 poin ( $1=$ sangat tidak setuju, $2=$ tidak setuju, 3=netral, 4=setuju, 5=sangat setuju). Kuesioner NEO PI-3 yang sudah dimodifikasi memiliki nilai Cronbach's alpha sebesar 0,780. Dimensi kepribadian pada penelitian ini terdiri dari neuroticism, extraversion, openness to experience, agreeableness, dan conscientiousness (McCrae \& Costa, 1997). Sifat neuroticism dicirikan dengan kecenderungan mood dan emosi yang tidak stabil seperti rasa bersalah, marah, cemas, dan depresi (Sitaraman, 2014). Sifat extraversion dicirikan dengan memiliki 
kemampuan bersosialisasi yang baik, memiliki banyak teman, dan keikutsertaan dalam suatu organisasi/ perkumpulan (John et al., 2008). Selanjutnya, sifat openness to experience dicirikan dengan seseorang yang memiliki imajinasi, kreativitas, rasa penasaran, dan rasa toleransi (Sitaraman, 2014).

Dimensi kepribadian berikutnya adalah sifat agreeableness yang dicirikan dengan memiliki sifat mudah memaafkan orang lain dan menjunjung tinggi kerjasama (John et al., 2008). Dimensi terakhir kepribadian dalam penelitian ini adalah sifat conscientiousness yang dicirikan dengan memiliki kemampuan memimpin, membuat rencana jangka panjang, dan keahlian yang bersifat teknis (John et al., 2008).

Situasi adalah atmosfir pada suatu lingkungan, serta merupakan pengaruh dari lingkungan di sekitarnya (Eertmans, 2006). Pengukuran situasi menggunakan kuesioner hasil modifikasi dari Alamsyah (2010) dengan jumlah 6 pernyataan yang berisikan 6 situasi saat mengonsumsi sayur. Kuesioner untuk mengukur situasi tersebut menggunakan skala likert 1-5 (1=tidak pernah, 2=jarang, 3=kadangkadang, 4=sering, 5=selalu) dan memiliki nilai Cronbach's alpha sebesar 0,743.

Pemilihan makanan adalah cara seseorang dalam mempertimbangkan pilihan makanan khususnya sayur untuk dikonsumsi, yaitu kesehatan, suasana hati, kemudahan, sensorik, kandungan alami dalam pangan, harga, pengendalian berat badan, familiaritas, dan masalah etika (Steptoe et al., 1995). Pengukuran pemilihan makanan, menggunakan kuesioner bernama Food Choice Questionnaire (FCQ) dari Steptoe et al. (1995) yang berisi 35 pernyataan dan menggunakan skala Likert 5 poin (1=sangat tidak setuju, 2=tidak setuju, 3=netral, 4=setuju, $5=$ sangat setuju). Kuesioner FCQ memiliki nilai Cronbach's alpha sebesar 0,938. Kuesioner bernama Food Frequency Questionnaire (FFQ) digunakan untuk mengetahui jumlah, frekuensi, dan jenis sayur yang dikonsumsi oleh mahasiswa sebelum dan sesudah masuk IPB. Kuesioner FFQ diadopsi dari penelitian milik Eertmans (2006).

Data primer diperoleh dengan cara mengunjungi langsung responden pada 3 kelas di gedung CCR (Common Classroom) yang terpilih menjadi klaster pengambilan data, yaitu kelas P09, Q03, dan R02. Kuesioner dibagikan secara merata kepada seluruh mahasiswa dari ketiga kelas tersebut.
Sebelum pengisian kuesioner dilaksanakan, mahasiswa dijelaskan terlebih dahulu mengenai tata cara pengisian kuesioner agar kuesioner yang diisi menghasilkan data yang akurat. Data dikumpulkan dengan teknik selfadministered, yakni mahasiswa sebagai responden mengisi secara mandiri kuesioner yang diberikan.

Data primer yang diperoleh diolah melalui proses cleaning, scoring, dan recording, serta analisis data. Pengolahan dan analisis data dilakukan dengan menggunakan program Microsoft Excel dan Statistical Package for Social Science (SPSS) for Windows. Data karakteristik mahasiswa tingkat pertama (usia dan jenis kelamin) dianalisis secara deskriptif. Analisis data statistik yang digunakan, yaitu 1) analisis statistik deskriptif untuk mengetahui kebiasaan konsumsi, deskripsi variabel kepribadian, situasi, dan pemilihan makanan; 2) uji beda (independent sample $t$-test) untuk menganalisis perbedaan variabel karakteristik mahasiswa tingkat pertama, kepribadian, situasi, dan pemilihan makanan menurut jenis kelamin mahasiswa tingkat pertama; dan 3) uji regresi linear berganda untuk menganalisis pengaruh karakteristik mahasiswa tingkat pertama, kepribadian, dan situasi (tempat makan) terhadap pemilihan sayuran.

\section{HASIL}

\section{Karakteristik Mahasiswa}

Jumlah mahasiswa tingkat pertama pada penelitian ini adalah 288 mahasiswa dengan proposi perempuan yang lebih banyak yakni sebesar 58,0 persen dibandingkan laki-laki sebesar 42,0 persen. Pada karakteristik usia, hasil menunjukkan lebih dari setengah mahasiswa tingkat pertama laki-laki $(57,9 \%)$ dan perempuan $(56,3 \%)$ berada pada usia remaja lanjut (16-18 tahun). Uang saku yang dimiliki mahasiswa tingkat pertama bersumber dari orang tua dan beasiswa. Sebaran uang saku per bulan yang dimiliki oleh mahasiswa tingkat pertama berada pada kisaran antara Rp300.000,00 sampai Rp5.000.000,00. Hasil menunjukkan bahwa proporsi terbesar uang saku yang dimiliki oleh mahasiswa tingkat pertama laki-laki dan perempuan antara Rp600.000,00 hingga Rp1.000.000,00 dengan proporsi mahasiswa tingkat pertama laki-laki sebesar 51,2 persen dan mahasiswa tingkat pertama perempuan sebesar 47,9 persen. Hasil uji beda menunjukkan bahwa terdapat perbedaan nyata signifikan pada uang saku per bulan antara mahasiswa tingkat pertama laki-laki dan perempuan $(p<0,05)$. 


\section{Kebiasaan Konsumsi Sayur}

Kebiasaan konsumsi sayur yang dialami oleh yang dimiliki oleh mahasiswa tingkat pertama dalam penelitian ini dapat memungkinkan untuk mengalami perubahan antara sebelum dan sesudah memasuki kehidupan di kampus IPB. Tabel 1 menunjukkan hasil sekaligus perbandingan jumlah, frekuensi, dan jenis sayuran yang paling sering dikonsumsi mahasiswa tingkat pertama antara sebelum dan sesudah masuk IPB.

Hasil penelitian ini menunjukkan bahwa terdapat perubahan konsumsi sayur dalam hal jumlah, frekuensi, dan jenis sayur antara sebelum dan sesudah masuk IPB. Temuan penelitian menunjukkan bahwa sebesar 46,7 persen mahasiswa tingkat pertama perempuan mengonsumsi satu mangkok sayur per hari sebelum masuk IPB, sedangkan setelah masuk IPB sebanyak 73,1 persen mahasiswa tingkat pertama perempuan hanya mengonsumsi setengah mangkok sayur per hari. Penyebab dari menurunnya jumlah konsumsi sayur dapat dikarenakan adanya kendala-kendala tertentu seperti ketersediaan sayur di kantin, ketertarikan mengonsumsi makanan lain selain sayur, kendala waktu yang membuat mahasiswa tingkat pertama lupa atau melewatkan jam makan, dan lain sebagainya.

Hasil pada Tabel 1 juga menunjukkan bahwa sebelum masuk IPB, baik mahasiswa tingkat pertama laki-laki $(52,1 \%)$ dan mahasiswa tingkat pertama perempuan $(60,5 \%)$ samasama memiliki frekuensi konsumsi sayur per hari sebanyak lebih dari dua kali. Sementara itu, mahasiswa tingkat pertama laki-laki $(38,0 \%)$ dan perempuan $(40,7 \%)$ mengalami penurunan frekuensi konsumsi sayur per hari menjadi hanya satu kali dalam sehari sesudah memasuki IPB.

Perununan frekuensi konsumsi sayur diduga disebabkan karena konsumsi sayur ketika mahasiswa tingkat pertama masih tinggal di rumah menjadi sesuatu yang mudah dan umumnya makanan disiapkan oleh orang lain seperti orang tua, saudara atau pembantu, sehingga mahasiswa tingkat pertama tidak perlu lagi mengeluarkan biaya dan tenaga untuk membeli sayur untuk dikonsumsi. Sementara itu, ketika mahasiswa tingkat pertama memasuki kehidupan kampus, khususnya tinggal di asrama, mahasiswa tingkat pertama harus bergerak sendiri untuk membeli makanan khususnya sayur di luar asrama.
Tabel 1 Sebaran mahasiswa tingkat pertama berdasarkan jumlah, frekuensi, dan jenis sayuran yang paling sering dikonsumsi sebelum dan sesudah masuk IPB (\%)

\begin{tabular}{|c|c|c|c|c|}
\hline \multirow[t]{2}{*}{ Kategori } & \multicolumn{2}{|c|}{$\begin{array}{l}\text { Sebelum } \\
\text { masuk IPB }\end{array}$} & \multicolumn{2}{|c|}{$\begin{array}{l}\text { Sesudah } \\
\text { masuk IPB }\end{array}$} \\
\hline & L & $P$ & $\mathrm{~L}$ & $P$ \\
\hline \multicolumn{5}{|l|}{ Jumlah } \\
\hline konsumsi/hari & 48,8 & 36,5 & 67,8 & 73,1 \\
\hline 1/2 Mangkok & 40,5 & 46,7 & 25,6 & 23,4 \\
\hline $\begin{array}{l}1 \text { Mangkok } \\
\geq 1^{1 / 2} \text { Mangkok }\end{array}$ & 10,7 & 16,8 & 6,6 & 3,6 \\
\hline \multicolumn{5}{|l|}{ Frekuensi/hari } \\
\hline Jarang/tidak & 9,9 & 13,8 & 24,8 & 38,3 \\
\hline pernah & 38,0 & 25,7 & 38,0 & 40,7 \\
\hline $\begin{array}{l}1 \text { kali } \\
\geq 2 \text { kali }\end{array}$ & 52,1 & 60,5 & 37,2 & 21,0 \\
\hline \\
\hline dikonsumsi & 9,1 & $\begin{array}{r}7,2 \\
\end{array}$ & 11,6 & 9,0 \\
\hline Sayuran tumis & 34,7 & 36,5 & 28,9 & 35,9 \\
\hline Sayuran mentah & & & & \\
\hline $\begin{array}{l}\text { Sayuran } \\
\text { berkuah }\end{array}$ & & & & \\
\hline
\end{tabular}

Jenis sayuran yang paling umum dijual atau dikonsumsi oleh masyarakat adalah sayuran tumis, sayuran mentah, dan sayuran berkuah sehingga ketiga jenis sayuran tersebut yang menjadi fokus dalam penelitian ini. Jenis sayur yang paling sering dikonsumsi sebelum memasuki IPB oleh lebih dari setengah mahasiswa tingkat pertama laki-laki $(56,3 \%)$ dan perempuan $(56,3 \%)$ adalah sayuran tumis. Sementara itu, hasil menunjukkan setelah masuk IPB cenderung tidak terjadi perubahan dalam pemilihan jenis sayuran yang paling sering dikonsumsi oleh mahasiswa tingkat pertama laki-laki $(59,5 \%)$ dan perempuan $(55,1 \%)$, yakni masih memilih jenis sayuran tumis.

\section{Kepribadian}

Rata-rata indeks kepribadian neuroticism mahasiswa tingkat pertama laki-laki dan perempuan berturut-turut sebesar 56,5 dan 59,0 (Tabel 2). Hasil penelitian menemukan adanya perbedaan nyata antara mahasiswa tingkat pertama laki-laki dan perempuan $(p<0,05)$ yang ditunjukkan dengan rata-rata indeks mahasiswa tingkat pertama perempuan lebih tinggi dibandingkan laki-laki. Mahasiswa tingkat pertama perempuan memiliki kecenderungan yang sedikit lebih tinggi untuk mengalami ketidakstabilan mood dan emosi dibandingkan dengan mahasiswa tingkat pertama berjenis kelamin laki-laki. 
Tabel 2 Rata-rata indeks kepribadian mahasiswa tingkat pertama dan hasil uji beda

\begin{tabular}{|c|c|c|c|c|}
\hline Dimensi & $\begin{array}{c}\mathrm{L} \\
(\mathrm{n}=121)\end{array}$ & $\begin{array}{c}P \\
(n=167)\end{array}$ & Total & $p$-value \\
\hline $\begin{array}{l}\text { Neuroti- } \\
\text { cism }\end{array}$ & $56,5 \pm 8,8$ & $59,0 \pm 9,6$ & $57,9 \pm 9,3$ & $0,023^{*}$ \\
\hline $\begin{array}{l}\text { Extrover- } \\
\text { sion }\end{array}$ & $58,4 \pm 10,2$ & $58,8 \pm 9,1$ & $58,6 \pm 9,6$ & 0,740 \\
\hline $\begin{array}{l}\text { Openness } \\
\text { to } \\
\text { experience }\end{array}$ & $56,6 \pm 9,5$ & $58,6 \pm 8,1$ & $57,8 \pm 8,8$ & $0,057^{*}$ \\
\hline $\begin{array}{l}\text { Agreeable- } \\
\text { ness }\end{array}$ & $52,5 \pm 8,2$ & $49,6 \pm 6,6$ & $50,8 \pm 7,5$ & $0,002^{*}$ \\
\hline $\begin{array}{l}\text { Conscien- } \\
\text { tiousness }\end{array}$ & $54,1 \pm 7,4$ & $53,7 \pm 6,0$ & $53,9 \pm 6,6$ & 0,594 \\
\hline
\end{tabular}

Perbedaan mood dan emosi mahasiswa tingkat pertama laki-laki dan perempuan dapat disebabkan perempuan memiliki volatility (emosi labil) yang lebih tinggi yang ditunjukkan dengan sifat mudah marah dibandingkan dengan laki-laki yang membuat perempuan memiliki skor neuroticism lebih tinggi, khususnya pada wanita ras Asia (Weiseberg et al., 2011).

Hasil uji beda menunjukkan bahwa tidak terdapat perbedaan nyata antara mahasiswa tingkat pertama laki-laki dan perempuan dalam kepribadian extraversion $(p>0,05)$ dengan ratarata indeks pada mahasiswa tingkat pertama laki-laki sebesar 58,4 dan mahasiswa tingkat pertama perempuan sebesar 58,8. Hal ini menunjukkan bahwa mahasiswa tingkat pertama memiliki kemampuan bersosialisasi yang cukup baik dan memiliki teman seperti mahasiswa pada umumnya.

Hasil pada Tabel 2 menunjukkan bahwa ratarata indeks mahasiswa tingkat pertama lakilaki sebesar 56,6 dan mahasiswa tingkat pertama perempuan sebesar 58,6 pada sifat openness to experience. Terdapat perbedaan nyata antara mahasiswa tingkat pertama lakilaki dan perempuan pada sifat openness to experience $(p<0,1)$. Hal ini berarti mahasiswa tingkat pertama perempuan memiliki kecenderungan yang sedikit lebih tinggi untuk memiliki sifat keterbukaan terhadap pengalaman yang ditunjukkan dengan memiliki rasa penasaran, toleransi, imajinasi, dan kreativitas yang cukup baik.

Dimensi kepribadian selanjutnya yaitu agreeableness, hasil menunjukkan bahwa rata-rata indeks mahasiswa tingkat pertama laki-laki sebesar 52,5 dan mahasiswa tingkat pertama perempuan sebesar 49,6. Hasil uji beda menemukan bahwa terdapat perbedaan nyata antara mahasiswa tingkat pertama laki- laki dan perempuan $(\mathrm{p}<0,05)$ yang ditunjukkan dengan rata-rata indeks mahasiswa tingkat pertama laki-laki sedikit lebih tinggi dibandingkan dengan mahasiswa tingkat pertama perempuan. Hal ini menunjukkan bahwa mahasiswa tingkat pertama laki-laki memiliki kecenderungan yang lebih tinggi pada sifat empati, baik hati, dan rela berkorban (Weiseberg et al., 2011).

Berdasarkan hasil penelitian, ditemukan bahwa capaian rata-rata indeks conscientiousness mahasiswa tingkat pertama laki-laki sebesar 54,1 dan mahasiswa tingkat pertama perempuan sebesar 53,7. Temuan penelitian menunjukkan bahwa tidak terdapat perbedaan nyata antara mahasiswa tingkat pertama laki-laki dan perempuan pada sifat conscientiousness $(p>0.05)$. Hal ini berarti baik mahasiswa tingkat pertama laki-laki maupun perempuan memiliki kemampuan memimpin, rencana jangka panjang, dan keahlian bersifat teknis yang cukup baik.

\section{Situasi}

Hasil pada Tabel 3 menunjukkan bahwa sebagian besar mahasiswa tingkat pertama lebih sering mengonsumsi sayuran ketika sedang berada di rumah dengan proporsi mahasiswa tingkat pertama laki-laki sebesar 62,8 persen dan mahasiswa tingkat pertama perempuan sebesar 44,9 persen. Situasi lainnya (makan di kantin, makan di restoran bersama teman-teman, ketika sedang berada di pesta, rekreasi bersama keluarga, dan makan siang) hanya berada pada frekuensi kadang-kadang. Berdasarkan temuan tersebut, maka situasi yang dipilih untuk diteliti lebih lanjut adalah situasi ketika makan di rumah. Hal ini karena sebagian besar mahasiswa tingkat pertama memiliki frekuensi yang paling sering dalam mengonsumsi sayuran ketika makan di rumah sehingga ingin diketahui lebih lanjut apakah situasi ketika makan di rumah memengaruhi pemilihan makanan responden dalam hal ini konsumsi sayur, atau tidak. Alasan utama mahasiswa tingkat pertama laki-laki dan perempuan dalam mengonsumsi sayur ketika berada di rumah berbeda. Alasan utama mahasiswa tingkat pertama laki-laki $(36,5 \%)$ adalah karena kenyamanan dan kemudahan, sedangkan alasan utama yang dipilih oleh mahasiswa tingkat pertama perempuan $(29,4 \%)$ adalah anjuran dari orang tua.

Hasil menunjukkan bahwa mahasiswa tingkat pertama perempuan $(49,1 \%)$ dan laki-laki $(54,5 \%)$ mengonsumsi sayur di kantin pada 
frekuensi yang kadang-kadang. Frekuensi terbanyak konsumsi sayur di kantin masih termasuk kadang-kadang dapat disebabkan oleh kurangnya ketersediaan sayur yang ada di kantin dan/atau terdapat harga makanan lain yang lebih murah dibandingkan sayur. Alasan utama mahasiswa tingkat pertama lakilaki $(46,3 \%)$ dan mahasiswa tingkat pertama perempuan $(47,3 \%)$ dalam mengonsumsi sayur ketika berada di kantin yaitu kenyamanan dan kemudahan. Alasan kenyamanan dan kemudahan disebabkan kantin memiliki jarak yang cukup dekat dengan asrama dan gedung perkuliahan sehingga mudah dijangkau dan mahasiswa tingkat pertama tidak perlu keluar kampus.

Hasil analisis juga menemukan mahasiswa tingkat pertama laki-laki $(43,8 \%)$ dan perempuan $(50,9 \%)$ mengonsumsi sayur ketika makan di restoran bersama temannya pada frekuensi kadang-kadang. Hal ini disebabkan karena ketika berada di restoran, terdapat menu makanan yang lebih banyak disukai oleh masyarakat umum khususnya kalangan anak muda dibandingkan dengan sayuran. Umumnya, makanan yang lebih banyak disukai anak muda ini cenderung kurang menyehatkan, seperti fastfood, daging, gorengan, dan makanan yang memiliki kandungan MSG tinggi. Alasan utama mahasiswa tingkat pertama laki-laki $(28,0 \%)$ dan perempuan $(27,2 \%)$ mengonsumsi sayur ketika makan di restoran sama, yakni kenyamanan dan kemudahan. Hal ini karena ketika berada di restoran, mahasiswa hanya perlu memesan menu sayuran yang dipilih tanpa harus menyiapkannya sendiri dan umumnya disediakan tempat yang nyaman.

Situasi ketika berada di pesta menunjukkan hasil bahwa mahasiswa tingkat pertama lakilaki $(52,1 \%)$ dan perempuan $(41,9 \%)$ memiliki frekuensi kadang-kadang mengonsumsi sayur. Hal ini dapat disebabkan karena menu makanan yang dihidangkan ketika berada di pesta umumnya lebih banyak yang bukan sayuran. Alasan utama mahasiswa tingkat pertama perempuan (34,8\%) dan laki-laki $(33,9 \%)$ mengonsumsi sayur ketika berada di pesta adalah kenyamanan dan kemudahan. Ketika berada di pesta, mahasiswa tingkat pertama hanya perlu memilih makanan yang dihidangkan di meja makan, sehingga mahasiswa tingkat pertama memiliki kebebasan dalam memilih makanan yang akan dikonsumsi. Selain itu, mahasiswa tingkat pertama juga tidak perlu mengeluarkan biaya untuk mengonsumsi makanan sehingga hal tersebut juga menjadi salah satu faktor kenyamanan dan kemudahan dalam mengonsumsi sayur pada situasi pesta.

Konsumsi sayur pada situasi makan siang umumnya dilakukan di tengah-tengah aktivitas mahasiswa tingkat pertama yang padat. Mahasiswa tingkat pertama laki-laki $(38,0 \%)$ dan perempuan $(47,9 \%)$ mengonsumsi sayur ketika makan siang pada frekuensi kadangkadang. Alasan utama mahasiswa tingkat pertama laki-laki $(31,7 \%)$ dan perempuan $(38,7 \%)$ mengonsumsi sayur ketika makan siang, yaitu pemenuhan kebutuhan energi. Hal ini disebabkan mahasiswa tingkat pertama memiliki kegiatan yang cukup banyak khususnya di siang hari yang meliputi kegiatan perkuliahan dan praktikum, mengerjakan tugas kelompok, kemudian pada sore harinya dilanjutkan dengan kegiatan organisasi maupun asrama sehingga konsumsi sayur ketika makan siang menjadi suatu hal yang penting sebagai sarana pemenuhan kebutuhan energi.

\section{Pemilihan Makanan (Sayur)}

Berdasarkan hasil penelitian ini, terdapat tiga kriteria pemilihan makanan dengan rata-rata indeks tertinggi, yakni kesehatan, suasana hati, dan kontrol berat badan. Hal ini menunjukkan bahwa mahasiswa tingkat pertama memiliki alasan pemilihan makanan yang berbeda, meskipun jenis makanan yang dikonsumsi sama, misalnya sayur (Yuliati et al., 2012).

Tabel 3 Sebaran mahasiswa tingkat pertama berdasarkan situasi dan frekuensi (\%)

\begin{tabular}{|c|c|c|c|c|c|c|c|c|c|c|}
\hline \multirow{3}{*}{ Pernyataan } & \multirow{2}{*}{\multicolumn{2}{|c|}{1}} & \multirow{2}{*}{\multicolumn{2}{|c|}{2}} & \multirow{2}{*}{\multicolumn{2}{|c|}{ Frekuensi }} & \multirow{2}{*}{\multicolumn{2}{|c|}{4}} & \multirow{2}{*}{\multicolumn{2}{|c|}{5}} \\
\hline & & & & & & & & & & \\
\hline & $\mathrm{L}$ & $\mathrm{P}$ & $\mathrm{L}$ & $\mathrm{P}$ & $\mathrm{L}$ & $\mathrm{P}$ & $\mathrm{L}$ & $\mathrm{P}$ & $\mathrm{L}$ & $\mathrm{P}$ \\
\hline \multicolumn{11}{|l|}{ Konsumsi sayur ketika: } \\
\hline Makan di rumah & 1,7 & 2,4 & 2,5 & 4,8 & 18,2 & 15,6 & 62,8 & 44,9 & 14,9 & 32,2 \\
\hline Makan di kantin & 3,3 & 5,4 & 9,1 & 11,4 & 54,5 & 49,1 & 29,8 & 28,1 & 3,3 & 6,0 \\
\hline Makan di restoran bersama teman & 9,1 & 9,0 & 25,6 & 20,4 & 43,8 & 50,9 & 19,0 & 13,8 & 2,5 & 6,0 \\
\hline Berada di pesta & 0,8 & 8,4 & 16,5 & 22,8 & 52,1 & 41,9 & 24,8 & 19,8 & 5,8 & 7,2 \\
\hline Rekreasi bersama keluarga & 3,3 & 6,6 & 13,2 & 16,8 & 52,1 & 32,3 & 25,6 & 30,5 & 5,8 & 13,8 \\
\hline Makan siang & 0,8 & 3,0 & 14,9 & 9,0 & 38,0 & 47,9 & 34,7 & 26,9 & 11,6 & 13,2 \\
\hline
\end{tabular}

${ }^{\bar{*}}$ Keterangan: 1=Tidak pernah; 2=Jarang; 3=Kadang-kadang; 4=Sering; 5=Selalu 
Tabel 4 Hasil uji regresi karakteristik mahasiswa tingkat pertama, tipe kepribadian, dan situasi terhadap pemilihan makanan

\begin{tabular}{|c|c|c|c|}
\hline Variabel Bebas & B & & Sign. \\
\hline Jenis kelamin ( 0 =laki-laki; $1=$ perempuan) & $-1,102$ & $-0,040$ & 0,470 \\
\hline Umur mahasiswa tingkat pertama (tahun) & $-0,251$ & $-0,012$ & 0,831 \\
\hline Uang saku (/000 rupiah) & $-7,959 \times 10^{-5}$ & $-0,004$ & 0,942 \\
\hline Neuroticism & 0,057 & 0,040 & 0,471 \\
\hline Extroversion & 0,163 & 0,119 & $0,035^{\star}$ \\
\hline Openness to experience & 0,208 & 0,139 & $0,013^{*}$ \\
\hline Agreeableness & 0,265 & 0,151 & $0,009^{*}$ \\
\hline Conscientiousness & 0,205 & 0,103 & 0,076 \\
\hline Situasi makan di rumah & 4,838 & 0,320 & 0,000 ** \\
\hline Konstanta & \multirow{3}{*}{\multicolumn{2}{|c|}{$\begin{array}{c}0,411 \\
7,652(0,000) \\
0,173\end{array}$}} & \\
\hline$F($ Sig.) & & & \\
\hline Adjusted $\mathrm{R}^{2}$ & & & \\
\hline
\end{tabular}

Keterangan: * $p$-value $<0,05$ ** sangat signifikan pada $p$-value $<0,001$

Suasana hati merupakan kriteria pemilihan makanan kedua dengan skor tertinggi, baik bagi mahasiswa tingkat pertama laki-laki $(66,7)$ maupun mahasiswa tingkat pertama perempuan $(66,3)$. Hasil penelitian menemukan bahwa tidak terdapat perbedaan antara mahasiswa tingkat pertama dan perempuan pada kriteria ini. Hal ini menunjukkan bahwa, baik mahasiswa tingkat pertama laki-laki maupun perempuan mementingkan kriteria suasana hati. Kriteria pemilihan makanan berupa kontrol berat badan merupakan salah satu kriteria yang paling banyak dipertimbangkan mahasiswa tingkat pertama dalam pemilihan makanan. Rata-rata indeks kontrol berat badan pada mahasiswa tingkat pertama laki-laki sebesar 64,5 dan mahasiswa tingkat pertama perempuan sebesar 67,1. Hasil analisis uji beda menunjukkan kontrol berat badan antara mahasiswa tingkat pertama laki-laki dan perempuan tidak terdapat perbedaan signifikan.

Hasil uji beda selanjutnya menemukan terdapat perbedaan nyata antara mahasiswa tingkat pertama laki-laki dan perempuan dalam hal kriteria pemilihan makanan berupa harga $(p<0,05)$. Mahasiswa tingkat pertama laki-laki memiliki rata-rata indeks lebih tinggi dibandingkan dengan mahasiswa tingkat pertama perempuan yang berarti mahasiswa tingkat pertama laki-laki cenderung lebih mementingkan kriteria harga dalam memilih sayur dibandingkan mahasiswa tingkat pertama perempuan. Selanjutnya, temuan penelitian menunjukkan rata-rata indeks kriteria familiaritas mahasiswa tingkat pertama laki-laki adalah 64,2 sedangkan mahasiswa tingkat pertama perempuan adalah 64,6. Kriteria pemilihan makanan untuk familiaritas tidak menunjukkan perbedaan nyata antara mahasiswa tingkat pertama laki-laki dan perempuan $(p>0,05)$. Mahasiswa tingkat pertama pada umumnya akan memilih jenis makanan yang sudah biasa dikonsumsi sejak lama. Pada kriteria masalah etika, tidak terdapat perbedaan nyata antara mahasiswa tingkat pertama laki-laki $(61,6)$ dan perempuan $(59,0)$

\section{Variabel Bebas yang Memengaruhi Pemilihan Makanan Mahasiswa Tingkat Pertama}

Hasil uji regresi linear berganda menunjukkan bahwa tipe kepribadian (extroversion, openness to experience, dan agreeableness) dan situasi ketika makan di rumah berpengaruh positif signifikan terhadap pemilihan makanan mahasiswa tingkat pertama (Tabel 4). Nilai Adjusted $R$ Square yang diperoleh sebesar 0,173 yang menunjukkan sebesar 17,3 persen variabel pemilihan makanan mahasiswa tingkat pertama dijelaskan oleh variabel bebas yang diteliti, sisanya dijelaskan oleh variabel bebas yang tidak diteliti.

Hasil uji regresi linear berganda, seperti yang tersaji pada Tabel 4, menjelaskan bahwa tipe kepribadian extraversion berpengaruh positif signifikan terhadap pemilihan makanan mahasiswa tingkat pertama $(\beta=0,163$; $p=0,035)$. Hal ini berarti mahasiswa tingkat pertama yang memiliki sifat senang bersosialisasi akan semakin memilih makan sayur dengan berbagai alasan. Selain itu, tipe kepribadian openness to experience juga berpengaruh positif signifikan terhadap pemilihan makanan mahasiswa tingkat pertama $(\beta=0,208 ; p=0,013)$. Hal ini berarti mahasiswa tingkat pertama yang memiliki sifat kreatif dan imajinatif cenderung semakin memilih makan sayur dengan berbagai alasan. Tipe kepribadian agreeableness juga berpengaruh positif signifikan terhadap pemilihan makanan mahasiswa tingkat pertama $(\beta=0,265 ; p=0,009)$. Hal ini berarti mahasiswa tingkat pertama yang memiliki sifat 
ramah dan peka terhadap lingkungan akan semakin memilih makan sayur dengan berbagai alasan.

Situasi ketika berada di rumah juga memiliki pengaruh positif signifikan terhadap pemilihan makanan $(\beta=4,838 ; p=0,000)$. Hal ini berarti situasi ketika makan di rumah memicu mahasiswa tingkat pertama untuk lebih sering mengonsumsi sayur. Sementara itu, model yang diuji tidak menemukan pengaruh jenis kelamin mahasiswa tingkat pertama terhadap pemilihan makanan sayur meskipun pada uji beda ditemukan beberapa fakta yang berbeda nyata antara mahasiswa tingkat pertama lakilaki dan perempuan.

\section{PEMBAHASAN}

Penelitian ini menunjukkan bahwa terdapat perubahan kebiasaan konsumsi sayur pada mahasiswa tingkat pertama sebelum dan sesudah masuk IPB dan asrama. Perubahan tersebut ditunjukkan dengan konsumsi sayur sebanyak satu mangkok menjadi hanya setengah mangkok setelah menjadi mahasiswa tingkat pertama. Perubahan lainnya ditunjukkan dengan menurunnya frekuensi konsumsi sayur yang awalnya lebih dari dua kali menjadi hanya satu kali dalam sehari setelah menjadi mahasiswa tingkat pertama. Jenis sayur yang paling sering dikonsumsi mahasiswa tingkat pertama antara sebelum dan sesudah menjadi mahasiswa tidak mengalami perubahan yang signifikan karena mahasiswa tingkat pertama masih memilih sayuran tumis sebagai jenis sayur yang paling sering dikonsumsi. Adanya perubahan yang terjadi pada jumlah dan frekuensi konsumsi sayur dapat disebabkan oleh ketersediaan sayur di kantin dan waktu makan yang terkadang dirasa terbatas karena adanya aktivitas perkuliahan atau organisasi.

Hasil penelitian ini menunjukkan bahwa mahasiswa tingkat pertama perempuan memiliki rata-rata indeks yang lebih tinggi pada tipe kepribadian neuroticism, extroversion, dan openness to experience. Hal ini menunjukkan bahwa mahasiswa tingkat pertama perempuan lebih cenderung memiliki sifat yang mudah marah dan stres (neuroticism), terbuka dan mudah bergaul (extroversion), serta memiliki imajinasi dan kreativitas yang baik (openness to experience). Hasil ini sejalan dengan penelitian dari Schmitt et al. (2008) yang menjelaskan bahwa perempuan memiliki skor yang lebih tinggi pada neuroticism dan extraversion, tetapi skor openness to experience pada laki-laki dan perempuan bervariasi tergantung dari budaya atau negaranya.

Berdasarkan hasil uji beda, terdapat tiga tipe kepribadian yang memiliki perbedaan signifikan antara laki-laki dan perempuan, yaitu neuroticism $(p<0,05)$, openness to experience $(p<0,1)$, dan agreeableness $(p<0,05)$. Menurut Schmitt et al. (2008), adanya perbedaan kepribadian antara laki-laki dan perempuan dapat disebabkan oleh semakin tingginya tingkat perkembangan manusia (Human Development Index) dan kesempatan yang lebih besar pada persamaan gender.

Situasi yang difokuskan dalam penelitian ini adalah situasi ketika makan di rumah. Pada situasi ketika makan di rumah, hasil menunjukkan bahwa sebagian besar mahasiswa tingkat pertama, baik laki-laki maupun perempuan, mengonsumsi sayuran dengan frekuensi yang sering. Hal ini menjelaskan bahwa konsumsi sayur pada mahasiswa tingkat pertama cenderung lebih sering ketika masih tinggal bersama orang tuanya, yakni sebelum mulai tinggal di asrama. Menurut Chan et al. (2009), remaja di Hong Kong cenderung mempraktikkan konsumsi makanan sehat ketika berada di rumah karena keberadaan ibu yang menjadi pihak paling berpengaruh dalam menyosialisasikan konsumsi makanan sehat. Berdasarkan hasil penelitian tersebut, dapat disimpulkan bahwa orang tua berperan penting bagi pemilihan makanan yang dilakukan oleh anak.

Hasil pada rata-rata indeks pemilihan makanan menunjukkan bahwa mahasiswa tingkat pertama perempuan menunjukkan indeks yang lebih tinggi pada kriteria kesehatan dan kontrol berat badan. Hasil ini sejalan dengan penelitian Wardle et al. (2004) yang menjelaskan bahwa perempuan cenderung lebih mementingkan aspek kesehatan dalam memilih makanan dengan menghindari makanan berlemak dan lebih memilih mengonsumsi makanan berserat dan buah-buahan.

Hasil uji beda menunjukkan bahwa terdapat perbedaan dalam hal pertimbangan harga dalam memilih makanan sehat. Mahasiswa tingkat pertama laki-laki lebih mempertimbangkan aspek harga dalam memilih makanan dibandingkan dengan mahasiswa tingkat pertama perempuan. Hasil ini sejalan dengan penelitian milik Missagia et al. (2012) yang menjelaskan bahwa laki-laki lebih memperhatikan murah atau tidaknya harga makanan, tetapi laki-laki tidak bersedia 
$\begin{array}{llr}\text { menghabiskan untuk } & \text { waktunya } \\ \text { membandingkan } & \text { harga pada beberapa }\end{array}$ makanan.

Hasil analisis regresi linear berganda menunjukkan bahwa tipe kepribadian extraversion berpengaruh positif terhadap pemilihan makanan. Hal ini berarti mahasiswa tingkat pertama yang senang bersosialisasi dan terbuka cenderung semakin meningkatkan konsumsi buah dan sayur. Hasil penelitian ini juga menunjukkan adanya pengaruh positif dari tipe kepribadian openness to experience terhadap pemilihan makanan. Lunn et al. (2014) menjelaskan bahwa orang yang memiliki skor openness to experience yang tinggi memiliki kecenderungan untuk memilih mengonsumsi makanan yang sehat dan lebih merasa terdorong untuk mengikuti pola hidup sehat. Oleh karena itu, mahasiswa tingkat pertama yang memiliki imajinasi, kreativitas, dan rasa penasaran cenderung menerapkan pola hidup sehat dengan mengonsumsi sayur. Hasil penelitian yang menunjukkan adanya pengaruh agreeableness terhadap pemilihan makanan sejalan dengan penelitian Kye \& Park (2012) yang menjelaskan bahwa orang yang memiliki skor agreeableness yang tinggi cenderung mengikuti pola makan yang sehat.

Hasil analisis regresi linear berganda menunjukkan bahwa situasi ketika makan di rumah berpengaruh positif terhadap pemilihan makanan. Kenyamanan dan kemudahan menjadi salah satu alasan bagi mahasiswa tingkat pertama dalam memilih mengonsumsi sayur di rumah. Pada umumnya, mengonsumsi sayur di rumah sudah memiliki persediaan bahan makanan untuk diolah dan tersedia fasilitas untuk mengolah bahan makanan tersebut. Hasil ini sejalan dengan penelitian sebelumnya yang dilakukan oleh Vandevijvere et al. (2009), yang mengatakan bahwa orang yang sering makan di rumah lebih tinggi konsumsi buah dan sayurnya dibandingkan dengan orang yang sering makan di luar rumah.

\section{SIMPULAN DAN SARAN}

Secara umum mahasiswa tingkat pertama mengalami penurunan konsumsi sayur dari segi jumlah dan frekuensi, sedangkan jenis sayuran yang dikonsumsi tidak mengalami perubahan dari sebelum dan sesudah menjadi mahasiswa. Tipe kepribadian neuroticism $(p<0,05)$, openness to experience $(p<0,1)$, dan agreeableness $(p<0,05)$ memiliki perbedaan nyata antara mahasiswa tingkat pertama lakilaki dan perempuan. Mahasiswa tingkat pertama laki-laki lebih cenderung bersifat agreeableness, sedangkan mahasiswa tingkat pertama perempuan lebih cenderung bersifat neuroticism dan openness to experience. Mahasiswa tingkat pertama laki-laki dan perempuan paling sering mengonsumsi sayur ketika berada di rumah. Pada pemilihan makanan, terdapat perbedaan nyata antara mahasiswa tingkat pertama laki-laki dan perempuan pada kriteria harga. Mahasiswa tingkat pertama laki-laki cenderung lebih mempertimbangkan harga dalam memilih makanan yang akan dikonsumsi. Hasil uji regresi linier berganda menunjukkan adanya pengaruh sifat kepribadian extraversion, openness to experience, agreeableness, dan situasi ketika makan di rumah terhadap pemilihan makanan pada mahasiswa tingkat pertama.

Bagi pemerintah, disarankan untuk membuat suatu program yang berkaitan dengan peningkatan konsumsi sayur, terutama bagi kalangan remaja. Bagi NGO atau LSM yang berkaitan dengan bidang kesehatan atau konsumen, disarankan untuk membuat suatu kampanye atau sosialisasi mengenai pentingnya konsumsi sayur terutama pada kalangan anak muda atau remaja agar remaja semakin terpapar mengenai informasi pentingnya konsumsi sayur; dengan mempertimbangkan kepribadian sebagai faktor yang memengaruhi anak muda dalam mengonsumsi sayur. Selain itu, dari pihak kampus agar menyeleksi secara ketat makanan yang dijual di kantin agar dan tidak terpapar oleh makanan-makanan yang membahayakan tubuh dan ketersediaan sayur di kantin tetap terjaga. Adapun saran untuk penelitian selanjutnya, yaitu dapat membuat alat ukur situasi yang dapat mempertimbangkan dimensi waktu, keberadaan orang lain (orang tua, teman), dan acara tertentu (saat pesta, rekreasi). Selain itu, disarankan dalam proses pengambilan data melakukan wawancara mendalam sehingga mendapatkan informasi yang didapatkan lebih banyak.

\section{DAFTAR PUSTAKA}

Achmad N, Hadju V, Salam A. (2014, September). Gambaran pengetahuan, sikap, ketersediaan dan pola konsumsi sayur dan buah remaja di makassar. Jurnal Masalah Konsumsi Sayur Remaja Makassar. Diambil dari http://repository.unhas.ac.id/handle/1234 56789/11319 
Alamsyah, Z. (2012). Analisis faktor-faktor yang memengaruhi pilihan jenis minuman pada berbagai situasi konsumsi dan dampaknya pada strategi pemasaran (Disertasi). Institut Pertanian Bogor, Bogor, Indonesia.

Brown, C., Shaibu, S., Maruapula, S., Malete, L., Compher, C. (2015). Perceptions and attitudes towards food choice in adolescents in Gaborone, Botswana. Appetite, 95, 29-35.

Chan, K., Prendergast, G., Gronhoj, A., \& Bech-Larsen, $\quad$ T. (2009). Adolescents'perceptions of healthy eating and communication about healthy eating. Health Education, 109, 474-490.

Choi, J., Zhao, J. (2012). Consumers' behaviours when eating out: does eating out change consumers' intention to eat healthily?. British Food Journal, 116, 494-509.

Eertmans, A. (2006). Sensory-affective and other determinants of food choice: their relative importance and variability across individuals and situations (Disertasi). Chatolic University of Leuven, Leuven, Belgia.

Ensaff H., Russel J., \& Barker M. E. (2012). Meeting school food standards-students' food choice and free school meals. Public Health Nutrition, 16(12), 21622168.

Gustiara, I. (2013). Konsumsi sayur dan buah pada siswa SMA negeri 1 Pekanbaru. Jurnal Precure, 1, 50-57.

Henningsen, M. (2011). Dietary habits in adolescence related to sociodemographic factors, physical activity, and self-esteem (Tesis). Norwegian University of Science and Technology, Trondheim, Norwegian.

John, O. P., Robins, R. W., Pervin, L. A. (2008). Handbook of Personality: Theory and Research. New York, NY: The Guilford Press.

[Kementerian Kesehatan]. (2013). Riset kesehatan dasar. Badan Penelitian dan Pengembangan Kesehatan-Kementerian Kesehatan. Diambil dari https://www.google.co.id/url?sa=t\&rct=i\& $\mathrm{q}=$ \&esrc $=$ s\&source $=$ web\&cd $=1 \& c a d=r j a$ \&uact=8\&ved=0ahUKEwi42IDekoXSAh WLM48KHVjPBb4QFggeMAA\&url=http \%3A\%2F\%2Fwww.depkes.go.id\%2Fres ources\%2Fdownload\%2Fgeneral\%2FHa sil\%2520Riskesdas\%25202013.pdf\&usg
$=\mathrm{AFQjCNH5N0m5ze5bOvcF9ja9z4da6w}$ pXyQ\&sig2=NFiJR1ap1P22IScelAHPcg. [diunduh pada 10 Februari 2017].

Keller, C., Siegrist, M. (2015). Does personality influence eating styles and food choices? Direct and indirect effects. Appetite, 84, 128-138.

Kye, S. Y., Park, K. (2012). Psychosocial factors and health behavior among Korean adults: a cross sectional study. Asian Pacific J Cancer Prev, 13, 49-56.

Laaksonen, M., Lalluka, T., Rahkonen, O., Roos, E., \& Lahelma, E. (2007). Multiple socio-economic circumstances and healthy food habits. European Journal of Clinical Nutrition, 61, 701-710.

Lunn, T. E., Nowson, C. A., Worsley, A., Torres, S. J. (2014). Does personality affect dietary intake?. Nutrition, 30, 403409.

Missagia, S. V., de Oliveira, S. R., de Rezende, D. C. (2012). Food choice motives and healthy eating: assessing gender differences. EnANPAD, 36, 2226.

Munro, I. A., Bore, M. R., Munro, D., Garg, M. L. (2011). Using personality as a predictor of diet induced weight loss and weight management. International ournal of Behavioural Nutrition and Physical Activity, 8, 129.

McCrae, R. R., Jr Costa, P. T., \& Martin, T. A. (2005). The NEO-PI-3: a more readable revised NEO personality inventory. Journal of Personality Assessment, 84, 261-

270.doi:10.1207/s15327752jpa8403_05.

Saufika, A., Retnaningsih, \& Alfiasari. (2012). Gaya hidup dan kebiasaan makan mahasiswa. Jurnal IImu Keluarga dan Konsumen, 5(2), 157-165.

Schmitt, D., Realo, A., Allik, J. (2008). Why can't a man be more like a woman? Sex differences in big five personality traits across 55 cultures. Journal of Personality and Social Psychology, 94, 168-182. doi: 10.1037/00223514.94.1.168

Sitaraman, G. (2014). Inferring big 5 personality from online social networks (Tesis). University of Washington, Seattle, UW.

Steptoe A., Pollard T. M., \& Wardle J. (1995). Development of a measure of the motives underlying the selection of food: 
the food choice questionnaire. Appetite, 25, 267-284.

Sumarwan, U. (2011). Perilaku konsumen: teori dan penerapannya dalam pemasaran edisi kedua. Bogor, ID: Ghalia Indonesia.

Vandevijvere, S., Lachat, C., Kolsteren, P., \& Oyen H. V. (2009). Eating out of home in Belgium: current situation and policy implications. British Journal of Nutrition, 102, 921-928. doi:10.1017/S0007114509311745.

Wang O., De Steur H., Gellynck X., \& Verbeke W. (2015). Motives for consumer choice of traditional food and european food in mainland china. Appetite, 87, 143-151. http://dx.doi.org/10.1016/j.appet.2014.12 .211 .

Wardle, J., Haase, A. M., Steptoe, A., Nillapun, M., Jonwutiwes, K., Bellisle, F. (2004).
Gender differences in food choice: the contribution of health beliefs and dieting. Annals of Behavioral Medicine, 27(2), 107-116.

Weiseberg, Y. J., DeYoung, C. G., Hirsh, J. B. (2011). Gender differences in personality a cross the ten aspects of the big five. Frontiers in Psychology, 2, 178.

World Health Organization. (2015, Juli). Promoting fruit and vegetable consumption around the world. Global Strategy on Diet, Physical Activity and Health. Diambil dari http://www.who.int/dietphysicalactivity/fru it/en/

Yuliati, L. N., Retnaningsih, Aprilia, D. (2012). Pengaruh kelompok acuan terhadap kesadaran dan konsumsi beras merah (Oryza nivara). Jurnal IImu Keluarga dan Konsumen, 5(2), 166-174. 